\title{
A República na obra de José Rodrigues Miguéis*
}

\author{
The Republic in José Rodrigues Miguéis' work
}

\author{
A. Paulo Dias Oliveira \\ Faculdade de Ciências Humanas e Sociais da Universidade do Algarve. Algarve, Portugal. \\ Faculdade de Ciências Sociais e Humanas - Universidade Nova de Lisboa/Universidade dos Açores.
}

\begin{abstract}
Resumo: O objectivo deste artigo é tentar compreender a perspectiva de José Rodrigues Miguéis em relação à República Portuguesa no período que vai de 1910 a 1926. Com esse fim em vista, procurou-se enquadrar as suas obras literárias no assunto em questão, com especial relevo para aquelas que tratam directamente desta problemática, ou seja, Escola do Paraíso, Idealista no mundo real e O Milagre segundo Salomé. Desse modo, pode-se asseverar que existem duas visões ou reflexos nas obras em análise, sendo, precisamente, esse duplo caminho que pretendemos pôr em destaque através da investigação das personagens.
\end{abstract}

Palavras-chave: José Rodrigues Miguéis; República (1910-1926); literatura; história.

\begin{abstract}
The main objective of this article is to understand the perspective of José Rodrigues Miguéis about the Portuguese Republic, in the period between 1910 and 1926. For this purpose, his works were framed under this subject, especially Escola do Paraíso, Idealista no mundo real and O Milagre segundo Salomé. Thereby, it can be assured that there are two visions or reflections on the analyzed works, being, precisely, this double path that is intended to be highlighted through the characters investigation.
\end{abstract}

Keywords: José Rodrigues Miguéis; Republic (1910-1926); literature; history.

Não resta qualquer dúvida que, para uma análise escorreita da noção daquilo que seria a República para Miguéis, era de todo indispensável a análise hermenêutica duma trilogia de obras que começa com A Escola do Paraíso, se prolonga no Idealista no mundo real e tem o seu ponto culminante em O Milagre segundo Salomé. É, precisamente, essa empreitada que adjudicámos.

Ao tomar tal encargo em mãos, temos consciência de que o autor nos confessa que "O Milagre segundo Salomé [e, por extensão, as duas outras obras] não é um romance histórico", mas uma "figuração simbólica de uma época, ambiente e estado de espírito colectivo" (MIGUÉIS, 1984 b, p. 345). O autor esclarece, em nota, que são os acontecimentos que levaram ao golpe de 28 de Maio de 1926. Contudo, mais à frente elucida-nos que "nem o mais sisudo e escrupuloso dos historiadores procede diferentemente do ficcionista, ao reconstituir através de documentos (nem sempre suficientes ou fidedignos), de indícios e palpites (nem sempre acertados), um passado

\footnotetext{
* Este artigo teve como ponto de partida a conferência proferida na Biblioteca da Universidade do Algarve, em Outubro de 2010, intitulada "Reflexos da República na obra Idealista no mundo real de José Rodrigues Miguéis".
}

que não presenciou. E não lhe damos nós crédito? $A$ diferença, aí, é que o autor deste romance presenciou muito do que narra, e de que dá testemunho e fé" (MIGUÉIS, 1984b, p. 348, itálico nosso) ${ }^{1}$.

Depois destas esclarecedoras palavras, a primeira coisa que gostaríamos de atestar é que, nas citadas obras de Miguéis, existe uma tensão, ou uma dialéctica que é termo mais técnico, entre o Ser e o Dever Ser. Passo a explicar: o livro possibilita-nos dois tipos de visão exegética, uma que nos conduz aquilo que, segundo Miguéis, a república terá sido $(\mathrm{Ser})$ e outra que nos leva de encontro aquilo que poderia ter sido (Dever Ser). É importante não abstrair que a obra de ficção postula, desde logo, uma certa categorização ontológica: o ser da ficção, que é primordial no sentido cronológico e substancial.

Desse modo, pode-se asseverar que existem duas visões ou reflexos da república portuguesa de 1910-1926 nas obras em apreço, sendo, precisamente, esse duplo

\footnotetext{
Esta perspectiva enunciada por Miguéis vai de encontro à nossa opinião pessoal de que não existe diferença significativa entre o conhecimento artístico, o conhecimento filosófico, o conhecimento histórico e o conhecimento da ciência natural. Não sendo este o lugar para discutir tais alvitres, remeto para uma obra indispensável, e quase diria clássica, em toda esta problemática (Feyerabend, 1981).
} 
caminho que pretendemos pôr em destaque através da investigação das personagens.

\section{As personagens significativas}

Tendo em atenção o que foi atrás enunciado, iremos enumerar os caracteres que, no nosso alvitre, revelam aquilo que foi a república: Mota-Santos, director do jornal Nação Republica é o modelo do político da época acompanhado do seu homem de mão o Robalinho; Severino Zambujeira, Cornelius-Hyppolite Vandenbeurs e Natário do Amaral, os plutocratas; e, ainda, o Milheiro das Barbas, ex-militante integralista que tinha aceitado um emprego público que lhe concedia réditos para o gozo da existência.

Numa perspectiva semelhante, só que situados do outro lado da barricada, temos Cabral dos Santos, o advogado dos operários de ideário libertário, o secretário da redacção da Nação Republicana, militante sindicalista e o Tio Amândio, velho libertário. A estes não podemos deixar de acrescentar a personagem principal do Idealista no mundo real, Deodato (dado por Deus), de sua graça, e os protagonistas de O Milagre segundo Salomé, Gabriel Arcanjo e Dores/Salomé, que, bem vistas as coisas, não podem deixar de estar do lado dos massacrados pelo regime.

Esta simpatia pelos deserdados perpassa toda a obra de Miguéis, porém, o romance onde isso se faz sentir de forma mais aguda, na nossa modesta opinião, é Miguéis (1982c). Na nota do autor se assegura que o romance foi feito "como se fosse para o povo" (MIGUÉIS, 1982c, p. 272). Por último, não deixa de ser curioso que o autor confesse, sendo que o tema desta obra é o "reviralho" da ditadura nacional, que trata da "revolução idealista no mundo real" ( $v d$. MIGUÉIS, 1982c, p. 135). Acerca da obra referida ver, ainda Alves (1982, p. 297, 299-301). Podemos, por último, encontrar, também, uma imagem do acrata, que é a personagem principal do conto "Saudades para D. Genciana" (MIGUÉIS, 1982b, p. 226-228).

Certifica-nos José Rodrigues Miguéis que "este romance [O Milagre segundo Salomé] devia constituir o terceiro painel do tríptico iniciado com A Escola do Paraíso, sendo-lhe o do centro o romance Filhos de Lisboa, ainda hoje por concluir devido às dificuldade de ordem afectiva, pessoal, que me suscita (o Gabriel dos Entremezes e da quarta parte é o mesmo que vimos crescer através daquele primeiro livro)" (MIGUÉIS, 1984b, p. 350).

De facto, o romance Filhos de Lisboa nunca foi concluído, mas, em grande medida, o Idealista no mundo real tomou esse lugar. Nessa ordem de ideias, auscultemse as afinidades entre o Deodato dessa composição e o Gabriel de $O$ milagre segundo Salomé. Veja-se em particular a referência ao primeiro em Miguéis (1984a, p. 255 ss., 283-284), onde a história dos dois se confunde: ambos colaboraram na Nação Republicana dirigida pelo Mota-Santos e acabaram como colaboradores da Sementeira, local onde se publicam os Entremezes. Sobre a participação de Miguéis na imprensa periódica (cf. MIGUÉIS, 1989a), aqui nos confessa o autor que terá escrito os seus primeiros textos no jornal República em 1922, (o diário foi fundado por António José de Almeida, em 1911, e por ele dirigido até à data da sua morte, 1929, posteriormente, ainda continuou a ser publicado até 1989, em 1974 era dirigido por Raúl Rego, opositor ao regime de Salazar) ( $v d$. MIGUÉIS, 1989a, p.63), além de ter realizado ilustrações para outros periódicos, por exemplo, a Alma Nova, onde, segundo o seu próprio testemunho, debutou literariamente ( $c f$. MIGUÉIS, 1989c, p. 40-41). Por último, de modo curioso os nomes das duas personagens também são quase idênticos: no Idealista no mundo real o herói é Deodato da Cunha Baltasar e em O Milagre segundo Salomé a personagem principal apelida-se de Gabriel da Cunha Baltasar, sobre este último (MIGUÉIS, 1984b, p. 199).

Por fim, duas figuras que encarnam o verdadeiro dever ser republicano: o Cavacas, que Deodato conhece aquando da sua estadia no tribunal do Sardinhal e por quem tenta desenvolver uma campanha para a sua libertação da cadeia e reabilitação e o Conselheiro Soares, irmão do presidente da república, que surge como uma espécie de figura tutelar (role model lhe chamam os americanos), encarnando o exemplo daquilo que devia ser o verdadeiro espírito republicano.

Aqui ainda haveria a hipótese de juntar a figura do Almirante, alter-ego de Mendes Cabeçadas, e do Major Tristão Barroso. Ambos aparecem como potenciais salvadores da República, acerca do primeiro (MIGUÉIS, 1984b, p. 176-180, 181-182). Acerca da figura de Tristão Barroso não podemos deixar de asseverar que ele, de facto, representa um certo pendor ético, embora, a sua associação umbilical ao General Adriano Belmarço e Couto, ou como é descrito em (MIGUÉIS, 1984a, p. 279), "Orapronóbsky", uma personificação do General Gomes da Costa, deixe essa perspectiva um pouco derreada.

A despeito de tudo isso, consulte-se a acção de Barroso (MIGUÉIS, 1984b, p. 45ss, 51, 87-102), o qual desenvolve um plano de ressurgimento nacional baseado no prestígio político, equilíbrio orçamental, "regularização da contabilidade pública", "morigeração administrativa", "austeridade" e "promoção da justiça fiscal". Conclui, por fim, numa visão próxima das doutrinas socialistas, que uma certa igualdade social e económica, quer dizer, "o direito de todos a um mínimo de regalias e garantias, de decência e utilidade, precede logicamente os direitos políticos: sem ela, estes não passam de ficção" (MIGUÉIS, 1984b, p. 101-102). 
Na nossa chã opinião, esta doutrina do "direito de todos a um mínimo de regalias e garantias, de decência e utilidade" aproxima-se da doutrina do "mínimo ético" de José Dias Ferreira, sobre esta doutrina conferir o seguinte: "há porém uma certa porção de bem, cuja realização, como indispensável à manutenção da vida humana, não pode ficar dependente dos caprichos ou vontade individual de cada homem. A conservação da vida social está de tal maneira dependente da realização objectiva desta porção de bem, que não pode satisfazer-se nesta parte só com a garantia da boa intenção: tão impreterível é a necessidade da realização desta porção de bem" (FERREIRA, 1864, p. 371). Esta asserção parece indicar uma prevalência da porção de bem sobre a liberdade de tal forma que, "à realização desta porção de bem é todo o homem obrigado, ainda mesmo que seja necessário recorrer ao extremo do uso de meios violentos. Este bem é património indispensável para a conservação da vida social. É fundo salvador da vida humana. É condição indispensável da observância da lei da igualdade entre os homens" (FERREIRA, 1864, p.371-372, os itálicos são nossos). Nesta perspectiva o mínimo ético transformase em mínimo social, isto é, real, efectivo, e esta sua efectivação objectiva, teria que ser vertida em acções positivas da prática do bem, pois o seu espírito assim o demandaria. Sobre esse conceito ver, ainda, Oliveira (2009, p. 440-443).

Tenha-se, finalmente, em conta que Barroso volta a conspirar assim que o 28 de Maio começa a "degenerar" e se instaura a ditadura (MIGUÉIS, 1984b, p.293). Mas vejamos cada um em pormenor.

\section{A República de facto}

\section{O Verso}

Nas palavras do Milheiro das Barbas, o Mota-Santos, "anda metido em tanta coisa. Deputado, o jornal, leader da minoria Ressurgista, o emprego, e sobra-lhe tempo para as negociatas: Turismo, carnes verdes e vermelhas, caminhosde-ferro, o Banco de Fomento... Sei eu lá" (MIGUÉIS, 1991, p. 212; MIGUÉIS, 1984a, p. 143). Por este pequeno excerto, vemos o tipo de personagem representado pelo director da Nação Republicana, o verdadeiro político da época que aparece como a verdadeira antítese do espírito republicano aos olhos de Deodato, e, por esse motivo, não espanta que o ex-integralista acrescente um pouco mais à frente: "um bocado corrompido, à luz das tuas ideias" (MIGUÉIS, 1991, p. 212), veja-se, na p. seguinte, a seguinte asserção do Milheiro: "ele está na oposição, mas governa-se melhor do que se estivesse no poleiro".

O carácter de Mota-Santos torna-se apodíctico na entrevista que mantém com Deodato, na qual o discurso do oportunismo político é por demais transparente. Veja-se, por exemplo, a seguinte asserção: "os senhores, a nova geração, têm de se habituar à ideia de que a democracia é o regime da livre concorrência, e que esta pressupõe a vitória da minoria dos fortes sobre a maioria dos fracos (...) a igualdade é uma linda palavra, mas não passa de aspiração" (MIGUÉIS, 1991, p. 219).

No mesmo sentido, consulte-se a seguinte asserção: "o que a massa [popular] admira é a personificação dos seus próprios desejos, polarizados no super-homem: César ou Napoleão, Robespierre, Lenine ou Mussolini. A história é obra deles" (MIGUÉIS, 1991, p.220). A expressão nietscheana, super-homem, não é aqui casual visto que mais à frente em Miguéis (1991, p.223), Mota-Santos refere, ainda, a vontade de poder. Ainda acerca dessas mesmas questões conferir, identicamente em Miguéis (1984a, p. 255-256). Embora não seja esta a ocasião indicada, não podemos deixar de salientar os equívocos que a obra póstuma $A$ Vontade de Domínio do filósofo alemão provocou, sobre a obra citada ver, por exemplo, Fink (1983, p. 163-193).

É, ainda, na mesma linha de pensamento que MotaSantos vai fazer coincidir a democracia republicana com as doutrinas evolucionistas no domínio social e político, de modo a fazer concordar estas com a luta pela vida, ou seja, o domínio dos mais aptos. Só nessa ordem de ideias se poderá entender que conclua que as doutrinas socialistas e quejandas são criações de desgraçados, de débeis, de incapazes, identicamente ao cristianismo que apelida de "seu irmão mais velho" (MIGUÉIS, 1991, p. 221). Tenha-se em conta, ainda, que Mota-Santos "teria pouco mais de quarenta anos, e vivia rodeado de clientela como um tribuno de Roma" (MIGUÉIS, 1991, p.221), esta identificação entre a personagem e um tribuno romano não me parece, de forma nenhuma, inocente, sendo as referências à clientela recorrentes.

Porém, o discurso do oportunismo político revelase verdadeiramente na seguinte passagem: "sabe que eu tenho fama de jacobino e mata-frades: fui-o, quando era oportuno. E no entanto, sou dos poucos, que, nesta terra, têm a coragem de reconhecer que só os jesuítas nos podem dar lições. Há muito que aprender com eles. É preciso ser jesuita, mas do avesso. Os jesuítas quiseram transformar o cristianismo, que era a arma dos fracos, em instrumento dos fortes. E o mesmo será preciso fazer com o socialismo (...) como força institiva, colectiva, o socialismo é uma grande arma, um reservatório inesgotável de potencial. Em democracia, o povo é por definição a grande matériaprima da opinião, do poder: mas quem é o povo? E que sabe ele, colectivamente, de economia, de governo, de leis da história? O povo é a mais volúvel das mulheres... Depois do pão e do circo, a primeira necessidade do povo é um chefe. O que é preciso é dar-lhe a ilusão embaladora 
de que é ele quem manda! E governá-lo. O mundo vive de ilusões, de ficções..." (MIGUÉIS, 1991, p. 222-223).

Veja-se o que o mesmo Mota-Santos assevera mais à frente ao tratar da sua própria biografia: "preguei doutrinas avançadas, o anarquismo, o amor livre, era eloquente e infatigável, fui preso e perseguido, aclamado pelos oprimidos" (MIGUÉIS, 1991, p. 225), a sua primeira aventura no jornalismo foi a edição dum jornal panfletário, simbolicamente intitulado, A Cloaca. Num momento posterior o próprio certifica que "desde jesuíta a bolchevista, e de talassa a jacobino, tudo me têm chamado: vendido à finança, agente da Espanha ou da Inglaterra, e até da Igreja... Só não me chamaram ainda invertido, porque tenho dado muitas provas de que o não sou" (MIGUÉIS, 1991, p. 240), esta última frase testemunha que de todas as outras coisas ele teria dado provas que o teria sido. Talvez, por esse motivo, se diga em MIGUÉIS (1984a, p. 140), que o Mota-Santos acreditava numa coisa essencial "a vida pela vida, o gozo...".

Atendendo a que o director do jornal começa a fazer a sua própria biografia e esta apenas nos vai revelar cada vez mais o seu oportunismo político, que se combina com uma atitude hipócrita, sentimento esse que vai levar Deodato a certificar que estava perante a biografia de um aventureiro, rodeado de clientela como um tribuno romano, e não de "um homem dedicado ao bem público" (MIGUÉIS, 1991, p. 226)². É precisamente esta conclusão a última palavra que se pode extrair da personagem: um aventureiro político, "um homem dinâmico e satisfeito, que fora anarquista (até bombista, ao que constava) e era agora republicano moderado, e falava de Mussolini com um brilho nos olhos" (MIGUÉIS, 1991, p.229, itálico nosso).

A personagem surge em todos os seus contornos no Idealista no mundo real e, provavelmente por essa causa, perde algum brilho em O Milagre segundo Salomé, surgindo, em demasia, associada à figura de Severino Zambujeira, num papel de conselheiro íntimo ${ }^{3}$. Sobre esse elo ateste-se a seguinte afirmação: "o Mota-Santos era o único amigo a quem ele ousaria confiar, mesmo com reserva, certos pensamentos. Apesar dos doze ou treze anos que os distanciavam tinham grandes afinidades: os começos difíceis, a subida enérgica e espectaculosa, as convicções democráticas, e um começo de pessimismo a respeito do regime" (MIGUÉIS, 1984a, p. 126).

Por outro lado, era verdade que diferiam muito em outras coisas, Mota-Santos era um orador temido e

\footnotetext{
2 Será, concerteza, por essa razão que, em (Miguéis, 1984a, p. 288), MotaSantos confessa a Severino Zambujeira que no jornal e no congresso nunca falava com franqueza.

3 Severino alcunha Mota-Santos de o seu "braço direito, político até ao tutano e homem de futuro" (MIGUÉIS, 1984a, p.293). A ligação entre as duas personagens pretende conotar esse elo essencial entre a política e a plutocracia, que Miguéis deseja pôr em relevo.
}

sentimental mas com um cinismo tremendo, "constava que vivia num autêntico serralho, com duas ou três mulheres, fora as pretendentes que as circunstâncias dos vários cargos que exercia lhe faziam passar entre as mãos sábias, curtas e morenas, todas, no dizer dele, lhe pagavam tributo" (MIGUÉIS, 1984a, p.126). Por essa circunstância, não é signo de espanto que quando Severino Zambujeira pretendeu arranjar companhia, o Mota-Santos tenha tido artes de lhe apresentar Dores/Salomé, fazendo, desse modo, a ligação entre as duas personagens centrais do enredo.

Esta personagem tem no Robalinho o seu homemde-mão, sendo este jovem, aloirado, a tender para o gordo e palrador "um dos íntimos do director, encarregado de lhe chamar os táxis e de introduzir as visitas discretas no gabinete particular: mulheres intensamente perfumadas, de véu caído para a cara, que se esgueiravam como enguias ao longo dos corredores" (MIGUÉIS, 1991, p. 244; sobre a mesma personagem, ver Miguéis (1984a, p. 141-142). O Robalinho mantinha com as aventuras do patrão intimidades de alcoviteiro como que a estender o poder do tribuno até si. Não restava qualquer dúvida, que essas mulheres "eram decerto burguesinhas que faziam o seu treino, ou procuravam emprego fácil, algumas porventura esposas de funcionários, de políticos menores, de negociantes em maus lençois" (MIGUÉIS, 1991, p. 244).

Tal como o Milheiro tinha servido de intermediário para a convivência com o Mota-Santos, vai este último servir de mediador para o conhecimento do industrial Natário do Amaral, o modelo do plutocrata republicano apresentado como "um grande homem de acção e de bem. Um verdadeiro self-made-man" (MIGUÉIS, 1991, p. 236). Sendo que o director do jornal aproveita logo para lembrar Deodato que a advogar se podia fazer riqueza, sendo apresentado a benéficos fregueses como Natário do Amaral que remuneram excelentemente, com todas as alcavalas que daí derivam.

O industrial começa logo por interrogar o herói para saber se este está inscrito no partido, e, tomando conhecimento da negativa, alvitra: "sem política não se chega a parte nenhuma. Sempre houve e há-de haver governos. E a república precisa de gente educada, de homens ilustres" (MIGUÉIS, 1991, p. 238). Aproveitando para fazer o elogio do amigo concluindo que esse sim, é um político à altura.

No entanto, a verdadeira figura do plutocrata é Severino Zambujeira e O Milagre segundo Salomé é a história da sua vida desde os dezasseis anos "e a sombra de um buço na carantonha lorpa" até "ao banqueiro à força de pulso". Tinha sido o Sr. Serrano que o havia recolhido quando andava vagueando na grande cidade, e, se o primeiro se tinha finado com a monarquia, Severino tinha-se erguido com a República. 
A personagem tinha-se enchido de patriotismo republicano com os Centenários, com o Ultimato e o 31 de Janeiro de 1891, no Porto. Levado nessa onda, tinha-se dedicado à leitura de jornais republicanos e assistido a comícios onde a palavra inflamada dos tribunos o comoveram sentindo-se parte de qualquer coisa. Nessa ordem de ideias, "filiara-se no partido Republicano e na Associação do Registo Civil; na Maçonaria fora crismado de "irmão Demóstenes". Assinara $O$ Mundo $^{4}$ desde o primeiro número, em 1900, e contribuía generosamente para as cantinas e creches escolares" (MIGUÉIS, 1984a, p. 161). Desse modo, considerava Zambujeira que o "Rei, partidos, titulares, parlamentos, conselheiros de lenço e de rapé, justiça, tropa, abades faunescos e jesuítas arteiros, eram a cambada" (MIGUÉIS, 1984a, p. 161).

Foi no seguimento de toda esta doutrinação que colaborou com os revoltosos oferecendo o armazém para ocultar material bélico, chegando mesmo a ter alguns recontros com a autoridade monárquica aquando da detenção de Manuel de Arriaga, safando-se, por um triz, de uma consulta com o temível Juiz Veiga. Por todos os motivos carreados, "quando, a 5 de Outubro de 1910, o trono baqueou, Severino Zambujeira, republicano histórico por direito próprio, com o Smith do senhor Serrano à cinta, sem dar um tiro, arvorou a bandeira verde-rubra à porta do armazém" (MIGUÉIS, 1984a, p. 164) e começou para o nosso herói uma época de "seguro progresso".

Esse progresso consubstanciou-se no negócio das carnes congeladas, numa negociata com alfarroba do Algarve, donde lhe derivou a alcunha de "Conde de Alfarrobo", mas, principalmente, com a empresa do Milagre. Esta última era uma "descoberta" do MotaSantos que lhe tinha certificado apodicticamente: "sim, o Milagre pode bem vir a ser o guião da unidade nacional, do futuro...", este pensamento começou a fazer eco na sua cabeça, sempre na procura de novos empreendimentos. A coisa "fermentou, traduziu-se em algarismos, imagens, movimento. E, quase de súbito, Severino descobriu a mina" (MIGUÉIS, 1984b, p. 127).

A mercancia delineou-se com a ajuda de Vandenbeurs que convenceu a hierarquia religiosa e o Vaticano e, nessa ordem de ideias, Severino já conseguia visualizar a coisa em três dimensões: "um santuário grandioso, como o do Sameiro ou do Bom Jesus, talvez maior! A colunata à maneira de $\mathrm{S}$. Pedro, em Roma, mas muito mais modesta, está visto. Fontes monumentais de água milagrosa... escadarias, balaustradas... balneário, hotel - não um mas dois: um para os ricos, outro para os remediados. Acampamento para os peregrinos, a tanto

\footnotetext{
4 Jornal republicano dirigido por França Borges até à data da sua morte,
} 1915, ao que conseguimos apurar, o periódico ainda se publicou até 1936. por cabeça. Casas de saúde e repouso para doentes e aleijados, campos de desporto, parque automóvel... Sem falar no casino e no resto!" (MIGUÉIS, 1984b, p. 128). E tudo a bem da República como o Mota-Santos já tinha salientado, Severino não duvidava que o Milagre "fosse o acontecimento capital da nossa época, o ponto de viragem, o sinal de ressurgir de Portugal" (MIGUÉIS, 1984b, p. 162). Não podemos deixar de fazer eco da opinião de Gabriel no tocante à "negociata do Milagre". Para ele, "era como se a mãe de Jesus se houvesse matriculado numa repartição poeirenta do Estado laico" (MIGUÉIS, 1984b, p. 211).

Faltava apenas a propaganda pela imprensa e dessa o Mota-Santos ia encarregar-se, tornando a Nação Republicana o "órgão do Milagre republicanizado e da concórdia religiosa (...) a ninguém era lícito duvidar da imparcialidade do jornalista que, para assim falar, tinha de represar as suas fundas convicções de agnóstico e anticlerical" (MIGUÉIS, 1984b, p. 167). Fica apenas a nota de que, devido a esse facto, a publicidade e as tiragens do jornal ascenderam em flecha.

Se Severino Zambujeira é o exemplo típico do plutocrata nacional e, como já ficou esclarecido, $O$ Milagre segundo Salomé é o livro da sua génese e desenvolvimento, a sua "fotografia" estaria pouco completa sem se acrescentar algumas palavras sobre outra personagem que, imanente quase toda a obra, se torna patente na última e decisiva fracção do romance: o belga Vandenbeurs, por antonomásia, o "perfeito-homem-debem", que encarna a plutocracia internacional. Eles são as duas faces da mesma moeda, e, se Severino Zambujeira é o "Conde de Alfarrobo", Cornelius-Hyppolite Vandenbeurs é o "Rei do Congo", belga por sinal.

Não temos como escopo fazer uma análise minuciosa do discurso encomiástico do "perfeito-homem-de-bem" (MIGUÉIS, 1984b, p.187-198, 237-249 e 273-285). Porém, não podemos deixar de pôr em relevo algumas linhas de força que nos ajudem a caracterizar o carácter dessa personalidade.

O belga foi um dos criadores dessas empresas que tiveram um fulgurante desenvolvimento, "vendendo a gregos e troianos sem discriminação, mantendo viva em plena guerra o espírito de paz e cooperação internacional, e contribuindo a par disso para acelerar a decisão do conflito, e poupar assim muitas vidas e bens". Desse modo, "o minério de ferro da Rendânia voltava a esta sob a forma de chuva de obuses e granadas; o carvão da Brancónia e do Lyttenburgo ia à Lamagna e à Rendânia aquecer os altos-fornos donde saiam os tanques e canhões das ofensivas contra a Brancónia, etc.". Concluindo, de sopetão, que não se podia "conceber forma mais subtil nem mais elevada de internacionalismo. Isto, meus senhores, é o que se pode chamar génio de cooperação para o bem geral!" (MIGUÉIS, 1984b, p. 237-238). 
O discurso apresenta ainda algumas sequelas das quais nos apraz apresentar as seguintes: "chegou-se mesmo à perfeição de proibir que fossem bombardeados, em território nacional ocupado pelo inimigo, os centros de produção empenhados em abastecê-lo de material de guerra". Na mesma senda proclama que é imperioso "levar a guerra até ao fim, objectivo para o qual são precisas armas e mais armas, munições, transportes, dinheiro e homens e, por esse motivo, as fábricas funcionam dia e noite" (MIGUÉIS, 1984b, p. 238-239). Desde logo, não podemos deixar passar em claro o fundo profundamente irónico de toda a exposição laudatória que atinge o seu pico um pouco mais à frente com os lapsus linguae que Freud, e todos nós, podía explicitar.

Nessa mesma explanação se põe em evidência que, mais fortes e importantes que os elos de família ou linguísticos, são as relações insolventes da economia, da indústria e da finança (MIGUÉIS, 1984b, p. 240). Veja-se, similarmente, a seguinte asseveração: "talvez a história venha a dar relevo, um dia, à acção, ainda hoje imprecisamente definida deste moço diplomatafinanceiro a favor da intervenção da grande pluto..., perdão, democracia de além-mar" (MIGUÉIS, 1984b, p. 242). Por último, não posso deixar de pôr em destaque a analogia entre o discurso sobre o "nosso Vandenbeurs", principalmente Miguéis (1984b, p. 243-244), e a argumentação expendida na obra de Pessoa (2006).

É, dessa forma, que se explica a formação da SêGê (Sociedade Geral de Investimentos, Descontos e Empresas Imobiliárias), "verdadeiro colosso cujos tentáculos, ou melhor dizendo, empreendimentos, se estendiam a grande parte do globo, através da rede imensa e quase inextrincável das mais variadas empresas independentes, filiais e subsidiárias". Correndo as coisas dessa feição, "a voz da SêGê chegava aos governos, aos parlamentos, aos congressos internacionais, e às festas coroadas. Não faltava quem lhe atribuísse responsabilidades nas lutas intestinas que com frequência dilaceram as nações atrasadas". Concluindo, de modo peremptório, que a SêGê abria "as portas do futuro a golpes de cifrão, digo, de visão" (MIGUÉIS, 1984b, p. 245-246). A argumentação ainda rematava que Vandenbeurs "podia enfim discutir de igual para igual com os seus amigos da Vespúcida" (MIGUÉIS, 1984b, p. 273), essa plutocracia, digo, democracia do além-mar.

Em toda esta problemática, há que ter em conta que a república de 1910-1926 não só manteve os monopólios que herdou da monarquia constitucional, como, ainda alargou esses monopólios a outras actividades industriais e facultou bastos privilégios aos capitalistas. Foi uma verdadeira república plutocrática. Talvez por esse motivo é que o Milheiro diz ao confrade: "sabes tu quem é o Rei de Portugal? Não sabes, pois digo-te eu: é o Tomlison, o director do Banco Inglês" (MIGUÉIS, 1984b, p.214). Ver, do mesmo modo, Miguéis (1984a, p. 290), onde se certifica que "afinal, quem manda nisto tudo é o Tomlinson do Banco Inglês e o Vandenbeurs dos Combustíveis". Ver, identicamente (MIGUÉIS, 1984a, p.192), onde se insinua, logo, o mote do mal radical da República do seguinte modo: "sabe você qual é o mal, o grande mal disto tudo?" E a resposta, sussurrada, não se faz esperar demasiado: "é a finança, a finança! Schiu....".

Falta-nos, apenas, articular algumas ideias acerca da personagem mais complexa, a seguir ao próprio Deodato, do Idealista no mundo real: o Milheiro das Barbas, correlegionário do herói em Coimbra e por este lançado "no mundo da capital". Devemos atestar que, para o Dr. Baltasar, o Mota-Santos era "tão aparentado no fundo ao Milheiro tradicionalista" (MIGUÉIS, 1991, p. 223) que bem podiam fazer um par.

O Milheiro simboliza o nacionalismo "truculento e reacionário" (MIGUÉIS, 1991, p. 60) da hoste integralista. O próprio Miguéis, que fazia parte dos adversários seareiros (a Seara Nova é abundantemente referida na obra debaixo do anagrama semântico de $A$ Sementeira) da doutrina integralista, faz a história do credo a propósito da biografia do Milheiro. É essa mesma história que veremos de seguida.

O colega "tinha sido um militante muito lido em neotomismo, um tradicionalista intransigente em perpétuo conflito com o regime e os seus homens, e obstinado em desacreditá-los". É do conhecimento geral que "a época fora de reacção tumultuária contra o 'jacobinismo' e a 'república burguesa'” (MIGUÉIS, 1991, p. 162). É, também, facto que a entrada de Portugal na Grande Guerra e a crise que sobreveio tinha concorrido para voltar grande parte da juventude contra o regime, a isso juntava-se a paradoxal preocupação com o olvidar da tradição.

De início, as movimentações ocultaram-se atrás da figura de Nuno Álvares Pereira e em vagos desejos de acabar com a decadência nacional, "fora e acima dos partidos". Perante a apatia do poder, tomou forma na Lusa Atenas e num impulso vingativo quis reduzir a cinzas os símbolos da República. Desse modo, os jovens desertavam das fileiras do regime, exigiam Ordem, cultivavam a Autoridade, desprezavam a Igualdade e requeriam Disciplina. Todos gritavam "palavras de sentido obscuro, por isso mesmo tanto mais electrizantes: Raça, Crença, Tradição, Família, Monarquia Orgânica, Casa dos Vintee-Quatro - num grande gasto de maiúsculas inspiradoras de sacrossantidade. As caravelas, as cruzes de Cristo e os pelicanos multiplicavam-se por toda a parte, inclusive nas paredes e nos mictórios públicos" (MIGUÉIS, 1991, p. 162-163).

Não se pode, similarmente, esquecer que o Integralismo Lusitano tentou cativar os sindicalistas 
desiludidos, alguns intelectuais, comerciantes desiludidos com o sistema fiscal, "a todos prometia regalias e liberdades medievais. Havia ideias, organização, cacetes e mocas, e até pistolas escondidas" (MIGUÉIS, 1991, p. 163). É neste movimento que, em Coimbra, vai participar o Milheiro, lido nos Mestres da ContraRevolução, com o "seu ardente proselitismo, desfrutou da autoridade, tornou-se a encarnação do Verbo, o símbolo e o chefe acatado duma geração que via no Passado em bloco a panaceia dos males da Pátria" (MIGUÉIS, 1991, p. 164$)^{5}$.

A despeito disso tudo, por este ano de 1923, que é o tempo da narrativa (MIGUÉIS, 1991, p. 166) ${ }^{6}$, já o Milheiro não era dos mais fiéis seguidores do Movimento do Integralismo Lusitano, pois, como confessa ele ao seu confrade, "quanta loucura e quanta sinceridade! Já hoje não aprovo tudo quanto divinizei" (MIGUÉIS, 1991, p. 162), reconhecendo, também, que se afastou de toda a militância.

Curiosamente, em O Milagre segundo Salomé quase toda a referência ao Movimento do Integralismo Lusitano desaparece, notando-se, apenas, ligeiras referências em Miguéis (1984a, p.234-235; 1984b, p. 45, 48, 89). Este facto pode ser explicado pelo quase marasmo em que o Integralismo Lusitano caiu, em primeiro lugar, após o Pacto de Paris, 1922, e, seguidamente, a morte de António Maria de Sousa Sardinha, Janeiro de 1925. Ou por qualquer outra razão que, neste momento, nos escapa.

\section{O Reverso}

Por esse motivo, está na hora de nos debruçarmos sobre o "outro lado da barricada". Uma das figuras que surge em relevo é a do advogado do operariado, Cabral dos Santos. A primeira notícia que dele temos é através dum colega, homem brilhante no foro que tem fama de ganhar todos os casos em que participa, por meios lícitos ou não, que nos certifica que "eu e o Cabral dos Santos somos o Contencioso dos Sindicatos Operários. Mas os casos que pagam vêm todos ter comigo; as espigas são todas para o Cabral" (MIGUÉIS, 1991, p. 104).

Fica-se na dúvida se o tal colega, Belarmino de sua graça, faria parte de uma rede que se servia da justiça a seu belo prazer. Nas palavras de Deodato existiria "um vasto sindicato - Crime Organizado Lda. - [que] estendia os seus tentáculos aéreos e subterrâneos por

\footnotetext{
5 Para a referência completa do papel do Milheiro no movimento, veja-se Miguéis (1991, p. 164, 165, 281ss).

6 Neste trecho trata-se do Presidente da República, António José de Almeida, que num acto de boa vontade impunha o barrete cardinalício ao Núncio Papal Achilles Locatelli, facto que data de 1923, ver, ainda, Miguéis (1991, p. 182) onde se diz que de 1864 se passaram "quase sessenta anos de progresso e mudanças de regime". Sobre a capita questão religiosa pode, entre outros, consultar-se Moura (2010), onde a autora nos dá uma visão minuciosa sobre este conflito entre a Igreja e o Estado, o qual não vamos, neste momento e por razões óbvias, examinar.
}

todos os serviços da Justiça (...) todos falavam disso, mas ninguém tomava medidas para bem da Justiça, da honra profissional, da dignidade forense. O Crime era uma fatalidade social, e dela todos se aproveitavam conforme podiam" (MIGUÉIS, 1991, p. 114).

Cabral dos Santos tinha posto toda a sua "inteligência e cultura ao serviço de uma causa que lhe era cara ao coração, a das organizações operárias, alienando logo ao começo da carreira, que prometia ser bem sucedida, toda a clientela endinheirada" (MIGUÉIS, 1991, p. 136). O que é facto é que o herói nutria por Cabral dos Santos uma afeição oculta, apesar de não partilhar o seu libertarismo utópico.

Em resultado de tanta decepção e engano, Cabral dos Santos decide recomeçar a vida em África, distanciado de "ambientes putrefactos", "de miséria interior", de "miasmas", de "degradação", os termos são da lavra da personagem, em paz com a sua própria consciência. Sendo que o destino das "vítimas da república" seja sempre um de dois: o exílio, no caso vertente, ou a resignação, como veremos no caso do Tio Amândio, figura analisada num capítulo, inserto na continuação do Idealista no mundo real, os Filhos de Lisboa, simbolicamente intitulado "Porque te calas Amândio". Sobre a questão do exílio veja-se o artigo de Lourenço (1990, p.269-281). Nessa análise, o autor faz uma distinção entre o exilado e o expatriado para concluir que a temática que lhe é própria é a do "homem, simultaneamente estranho e estrangeiro" (LOURENÇO, 1990, p. 273, sentimento que é por demais evidente em, por exemplo, Miguéis (1989d). Porém, uma outra coisa nos transmite Lourenço e de capital importância para este pequeno trabalho, o facto de "tudo o que conta na obra de Rodrigues Miguéis é intensa e obsessivamente autobiográfico" (LOURENÇO, 1990, p. 273).

Voltando à análise das personagens do texto, temos que o Secretário da redacção do jornal é apresentado como homem esguio, que ainda não devia andar próximo dos 40, mas já com sinais de senilidade acelerada, sem cor e de olhos claros. Na perspectiva do Dr. Baltasar, era "excelente profissional, com categoria para chefiar um grande rotativo, estava exilado naquela folha de terceira ordem porque o seu passado de lutas sindicais lhe fechara temporariamente o acesso a mais altos postos" (MIGUÉIS, 1991, p. 235). Apenas dele temos uma outra notícia, passado algum tempo, quando convida Deodato a juntar-se ao sindicato dos jornalistas.

Figura sintomaticamente do lado das vítimas é o Tio Amândio. Esta personagem aparece, apenas, na continuação do Idealista no mundo real. Todavia, a figura desponta no romance Escola do Paraíso onde é associado ao movimento libertário, aí se citam as suas leituras de A conquista do pão de Kroptkine, além de referências a 
Bakunine, à Internacional e à Comuna (MIGUÉIS, 1981, p. 341, 343, 344).

Porém, é no já citado Filhos de Lisboa que o tipo é desenvolvido, num capítulo alegoricamente intitulado "Porque te calas Amândio". Neste encontramos a história de um velho oleiro, um homem resignado - a resignação ou o exílio são, como já foi adiantado, as duas formas de resposta ao estado das coisas -, que na juventude era conhecido pela alcunha de "O Vermelho", não se sabe se devido à pigmentação capilar ou às ideias políticas e sociais, embora sejam as últimas que vão prevalecer no romance.

Esse homem agigantado nada tinha perdido dos ideais da sua mocidade, embora a existência o tivesse forçado a adoptar o que sempre tinha recusado. Ele, "O Vermelho", tinha-se tornado dono de fábrica em sociedade com um homem que tinha feito fortuna em Angola, tinha-se tornado explorador. Para ele, "era renegar os ideais". "Vieram as encomendas, meteram operários. E às duas por três o antigo libertário viu-se a braços com a concorrência, créditos, preços, descontos, conflitos, até uma greve... Sentiu-se olhado com ódio pelos excamaradas, esta gente nova que o não conhecia nem entendia. Sofreu muito, perdeu o sono (...) com as responsabilidades e as dores de cabeça do pequeno produtor, sem capital nem crédito, sempre atrás dos devedores que faliam ou não pagavam, e com os operários à perna, a reclamar o magro pão. A concorrência era muita, o tijolo baixava, a mão-de-obra, mal paga, comia o que a inflação deixava, o custo de vida sempre a subir, e apareceu o cimento armado" (MIGUÉIS, 1991, p. 357-358).

No fundo, era a própria história do operariado que se tinha dedicado à república de corpo e alma e apenas teve como recompensa a lei, de Brito Camacho, à época ministro do fomento, que dava ao governo o poder de usar todos os meios para coarctar, de forma célere e enérgica, qualquer protesto operário. É por esse motivo que Amândio e sua mulher Leontina, que passa a vida a atazaná-lo: "porque te calas Amândio", simbolizam a relação conflituosa entre a república e o operariado, forçado a resignar-se.

Apenas isso explica a atitude do dirigente da CGT que, aquando do golpe de 28 de Maio e demandado para a defesa da República, articula o seguinte discurso: "a República? Qual delas? A do Afonso Costa que assaltou e metralhou a União Sindical, e expulsou mulheres e crianças? A dos que mandam espingardear grevistas?. [De seguida, num lampejo de racionalidade operária remata]: tudo isto é apenas uma rixa no seio da família burguesa! O operariado não mete para aí prego nem estopa. Já deu demasiadas vezes o seu sangue. Seja quem for que governe - militares ou novos ricos, políticos ou intelectuais - é sempre a Ditadura da Burguesia. Não contem connosco. Muito boa tarde!" (MIGUÉIS, 1984b, p. 184)7.

Não podíamos terminar este apartado sem falar da própria figura do herói da narrativa, Deodato da Cunha Baltasar. Já a escolha do nome Deodato não é inocente, como já foi posto em destaque, aliada à preocupação do autor para que fosse esse o nome pelo qual o herói devia ser conhecido tal como se pode discorrer das palavras da prefaciadora da novela: "o presente texto substitui de alto a baixo o nome "Baltasar" pelo nome "Deodato". Em ambos os exemplares, Rodrigues Miguéis riscou Baltasar e escreveu Deodato, ou simplesmente "D...". Além disso, um dos exemplares trazia a seguinte nota marginal: "Deodato! Sempre Deodato... os outros é que o chamam Baltasar"(MIGUÉIS, 1991, p. 17).

De facto, o narrador passa pela acção como uma vítima de expiação, desde os tempos remomerados de Coimbra na companhia do Milheiro das Barbas, passando pela Boa Hora, pela comarca do Sardinhal, onde encontra a sua alma gémea, o Cavacas de que falaremos de seguida, ou, ainda, na Nação Republicana. Apenas em $A$ Sementeira esse sentimento não é latente, embora dúvidas se levantem acerca da personalidade dos seus redactores ${ }^{8}$.

Por esse motivo, não espanta que Deodato tivesse da política "um conceito quase religioso, considerava-a a mais alta e nobre de todas as técnicas e artes: a de governar pelas ideias, segundo a vontade e para o bem do povo. A vulgaridade e o oportunismo dos políticos pareciamlhe um bluff monstruoso, uma corrupção da verdade (...) [estava] contra a demagogia, a improvisação, as facções, a brutalidade das armas ou da plebe açulada por interesses inconfessáveis".

Ou, ainda, que cresse que a política devia "ser uma grande devoção, austera e disciplinada, e uma ciência, ambas elas devotadas ao bem geral" (MIGUÉIS, 1991, p.238-239). Por tudo isto não espanta a identificação com a pureza da doutrina cristã (Deodato identificado a Cristo) que termina com a asserção "é por isso que eu sou socialista” (MIGUÉIS, 1991, p. 213).

Não podemos deixar de atestar que de capital importância para a percepção ética e humana das obras em apreciação são os entremezes que vão pontuando $O$ Milagre segundo Salomé. São eles que, conjuntamente, com a figura alva de Dores/Salomé, dão o toque da inocência às duas personagens. Não nos é possível fazer um estudo exaustivo destas peças, que passam da dezena. Porém, algumas características são por demais óbvias e

\footnotetext{
Não se pode omitir que, a maior parte das vezes, o operariado tinha dito presente na defesa da República, note-se, por exemplo, os episódios das incursões monárquicas (1911 e 1912) ou da Monarquia do Norte (1919).

8 Estas dúvidas simbolizarão a ruptura do autor com o movimento da Seara Nova? Sobre essa questão (vd. ALVES, 1982, p. 294-297).
} 
não existe razão lógica para elas não serem postas em saliência. São, precisamente, essas que iremos, agora, analisar.

A primeira, intitulada "Uma coisa anda no ar", avalia a força dos anarco-sindicalistas que ameaçam com a greve geral. Aqui se estampa que o seu órgão de imprensa (A Batalha - CGT) vende cerca de 50 mil exemplares diários, havendo "mesmo quem diga que vai nos 70 mil, capaz de bater os grandes rotativos. É uma coisa sem precedentes, uma ameaça, uma força de temer. Corre que o casarão dos Sindicatos, aos Paulistas, é uma verdadeira fortaleza: armas, bombas, organização" (MIGUÉIS, 1984a, p. 192).

$\mathrm{Na}$ mesma ordem de ideias, dois outros capítulos versam a questão do operariado. O primeiro que encena a greve geral e a manifestação dos trabalhadores que culmina no confronto entre as autoridades e os revolucionários da acção directa, o derradeiro que retrata o comício no Parque Eduardo VII que junta cerca de 10 a 12 mil pessoas, este tem a sua encenação final na marcha pela Avenida descrita do seguinte modo: "a massa põe-se em marcha aos 20 ou 30 de fundo, braço a braço, abrangendo de lés a lés a faixa central, onde não passa um carro nem se aventura um peão. A Avenida agora é deles. É a maior parada, sem armas, a que a cidade ainda assistiu" (MIGUÉIS, 1984b, p. 37). O desenrolar pacífico da manifestação silenciosa faz com que um transeunte se interrogue: "será que os desordeiros vão dar o exemplo da Ordem?" (MIGUÉIS, 1984b, p. 36).

Objecto de algumas reflexões é, também, o General ABC. Logo num dos primeiros textos se pretende exorcizar o messianismo providencialista, ou seja, a figura do grande homem que há-de salvar a República. É por esse motivo que o desejado Belmarço e Couto, aliás, "Orapronóbsky", fará "tudo por nós" e nós "esperamos sempre que um ente superior, sobrenatural, eterno Desejado, faça por nós aquilo que somos incapazes de, ou não estamos dispostos a fazer", ele é o "Homem-capazde-meter-isto-nos-eixos" (MIGUÉIS, 1984a, p. 278), Convém, ainda, adicionar que, nesse mesmo local, são sufragadas as suas ambições de poder.

Sabemos que este messianismo não era uma atitude nova na política portuguesa, pois já Antero acreditava, aconselhando-o nesse mesmo sentido, que Oliveira Martins podia ser a âncora que fornecesse fixidez à barca governamental, $v d$., entre outras, Quental (1989, p. 847-848). Nesta se declara que "estou muito mais disposto a admitir uma mais larga esfera de acção, um maior poder dos indivíduos excepcionais sobre a sociedade num período de tumulto e revolução, de crise declarada e de universal mea culpa. Uma dessas crises limpa o terreno de muitos embaraços (...) Assim, meu caro, acho que tem tudo a ganhar em esperar pelos acontecimentos e em se reservar. Os Messias gastam-se, se não entram logo em cena a fazer milagres", este último itálico é nosso.

Uma decisiva vez nos aparece o General, é aquando da revolta de 28 de Maio debaixo da epígrafe "Rei chegou e em Belém desembarcou". Aqui se conta o desembarque do militar vindo da Índia, para onde o governo o tinha "deportado", a fixação da residência em Braga e a marcha para Lisboa onde vai, sobrepondo-se ao Almirante, liderar o golpe de 1926, até ser, por sua vez, afastado pelas forças mais conservadores.

Só por uma questão de curiosidade refira-se que Sinel de Cordes é evocado uma vez, debaixo do anagrama de Cardal de Sines (MIGUÉIS, 1984b, p.46-47). Destaque-se, ainda, que o movimento fascista também é mencionado no mesmo volume (MIGUĖIS, 1984b, p. 49 e 294-295). Por último, assevere-se que a figura castrense é personagem quase omnipresente no romance, apenas por uma questão de curiosidade constate-se que o General ABC é aludido, além dos locais já citados (MIGUÉIS, 1984a, p. 197, 224-225, 228, 247-248, 249 ss.; MIGUÉIS, 1984b, p. 40, 41 ss., 53, 109-114, 143-147, 175, 293). Além disso, a personagem aparece-nos ainda no conto "Ele era o nosso paizinho" (MIGUÉIS, 1982a). Esta peça literária relata o dia do passamento do Marechal Orapronóbsky, no qual se reproduz as suas últimas palavras, "Morro bem, salvem as pratas", que a viúva, a única a ter ouvido este seu último desejo, transforma em "Morro bem, salvem a pátria" (vd., MIGUÉIS, 1982a, p.329). Acerca da questão das "pratas" (cf. MIGUÉIS, 1982a:326; 1984a, p. 294-301).

Para completar o quadro falta-nos apenas esquadrinhar a figura de Salomé. De facto, Dores/Salomé atravessa a narração como o sinal mais visível da inocência cátara, a despeito da sua profissão de prostituta, levada pelas circunstâncias num primeiro momento e retomada após o abandono de Severino Zambujeira e antes do encontro (que, de facto, é um verdadeiro reencontro das duas personalidades éticas do romance) com Gabriel. Ela é o signo do ideal da sublimidade moral, que se pressente na busca de Gabriel (não são os entremezes expressão dessa mesma demanda?), desde os tempos da relação com A. Tesouras, aliás, Aniceto Cutileiro, até ao desprendimento e inquietude da sua ligação com Severino Zambujeira.

Não é, por outro lado, o continuar da sua intimidade com a "Mouca", outra que encarna o timbre dessa pureza, indício disso mesmo? Por último, o amor entre os dois não resulta sempre virgem, puro, acima de qualquer marca material. Somos de opinião que toda a quarta parte do romance se constitui como um hino a esse sentimento.

Toda esta atitude se encontra plasmada em duas ou três afirmações do próprio Gabriel que passamos a 
enumerar. Segundo ele, a impressão que Salomé "dava era de candura e pureza", havia há muito suspeitado "nela a virgindade do coração, que era real" e, ainda, segundo a sua perspectiva os pequenos pastores tinham visto nela "a Virgem mãe de Deus, a encarnação da pureza, da virtude e do amor (...) viram-te como eras - e és (...) boa, virgem, maternal (...) tu és o autêntico e único milagre (...) tu colheste nele a redenção pelo amor". Por esse motivo, é que num momento de elevada exaltação a vai apelidar de "Santa Salomé" (MIGUÉIS, 1984b, p. 213, 233, 338-339 e 263).

\section{A República de direito}

Falta-nos, apenas, analisar as duas figuras, se abstrairmos outras enumeradas atrás que com elas se identificam, que estabelecem o padrão do dever ser republicano: o Cavacas e o Conselheiro Soares, irmão do presidente da república. Acresce que o presidente da república nesse ano de 1923, data, como já foi salientado, da narrativa, é António José de Almeida, o qual é referido de forma elogiosa, por mais que uma vez (MIGUÉIS, 1981, p. 113, 231, 333). A admiração pelo chefe do partido evolucionista aparece, ainda, em Miguéis (2004, p.69-70). Neste texto Miguéis admite que "foi pela mão dele, ainda em plena monarquia, que eu dei entrada nas convicções republicanas", (MIGUÉIS, 2004, p.69). No mesmo sentido, consultar (MIGUÉIS, 1989b, p. 90-91).

O primeiro contacto com a personalidade do Cavacas dá-se depois dum sarrabulho feito pela consorte aquando da penhora de bens, ao ouvir o nome, Deodato, recorda-se do caso ter sido noticiado por A Sementeira que o classificou de erro judiciário. $\mathrm{O}$ próprio esclarece que o seu caso é de conspiração, pois os seus adversários não se aprazem em o ter encarcerado, ainda vão mais longe e lhe confiscam os poucos haveres que possui, concluindo que essa "é a esperança dos meus inimigos: liquidar-me!” (MIGUÉIS, 1991, p. 196).

Chegamos, assim, à história do Cavacas, contada pelo director dum semanário do Sardinhal que, tendo feito campanha por ele, fora acusado e estivera com o periódico embargado durante uns tempos. Segundo ele, "este cidadão, alentejano há muito radicado no Sardinhal com um pequeno negócio de aprestos navais, é republicano histórico: em rapaz conspirou contra o João Franco, foi preso, e ia ser deportado quando se deu o regícidio. Bateu-se no cinco de Outubro (...) sem pedir diploma de "combatente". Nunca teve um emprego público, nem fez fornecimentos ao Estado. Deixou-se eleger, anos depois, para uma Junta de freguesia, onde se manteve em contacto com os pobres e as crianças, que sempre estimou. Apóstolo do mutualismo e da instrucção popular, organizou sociedades várias, uma cantina, recreios para meninos e adultos. Foi dos que trabalham sem colher louros nem esperar recompensa" (MIGUÉIS, 1991, p. 203).

Continuando a sua narrativa, asseverava que o Cavacas era homem honesto e recto e "via com desgosto que, pelo menos cá no concelho, a sua República caía nas mãos de acomodados e adesivos, de caciques profissionais, dadores de empregos e favores que tinham ajudado a cavar a sepultura à monarquia, e aos quais a República abria os braços... e os cofres. Viu formarem-se novas clientelas, semelhantes às antigas; e infiltrarem-se interesses privados na gestão da coisa pública. Legalista convicto, nunca pegou nem incitou ninguém a pegar em armas contra os governos. Era um sólido esteio da ordem na liberdade: e porque o era, pagou" (MIGUÉIS, 1991, p. 203).

Do outro lado vivia um homem que já tinha sido de todas as cores políticas (progressista, regenerador, dissidente franquista, republicano e até sidonista) acompanhando o poder, durante a guerra prosperou com mercadoria adulterada, industrial de peso não houve conflito armado contra a república que não tivesse participado. Ora bem, este homem candidata-se a presidente do município e ganha as eleições.

Foi então que o Cavacas provou com documentos irrefutáveis "que eu vi e estão felizmente a bom recato, que o candidato não era só um adversário do regime, mas um burlão escapo às malhas da Justiça, um especulador e provocador". O Cavacas "ameaçou publicar tudo se a maioria não repudiasse o candidato. Como era respeitado, e não o podiam atacar de frente, tentaram comprá-lo; depois recorreram às ameaças. Nada disso deu resultado. Cavaram-lhe então a ruína comercial: os bancos recusaram-lhe créditos e o desconto de letras, os fornecedores exigiram pronto pagamento, demandaramno por divídas, e chegaram a recusar abastecê-lo. Houve quem lhe devolvesse a mercadoria. Fechavam-lhe as portas na cara, e perseguiram-lhe os filhos na escola" (MIGUÉIS, 1991, p. 204).

O Cavacas foi apoiado pelo jornal, alguns políticos, independentes e descontentes de vários partidos, e pelos sindicalistas. Foi, então, que "quando anunciei que ia começar a estampar os documentos do Cavacas, fui agredido em plena rua; assaltaram-me e empastelaramme a tipografia, cortaram-me o fornecimento de papel. Chamaram-me talassa e bolchevista. Nada nos fez desistir" (MIGUÉIS, 1991, p. 205).

Então aconteceu o inevitável. Um primo do Cavacas, com quem ele estava desavindo, foi encontrado morto perto dum sítio onde o próprio tinha sido visto na noite anterior. Logo de seguida, foi preso e acusado de 
homicídio. A verdade é que o Cavacas tinha estado em casa duma lavradora casada e devido a pruridos morais, para com ela e para com a própria família, recusava-se a dizer onde se tinha deslocado. Algum tempo depois a amante, cheia de remorsos, veio depor em defesa do réu, mas o seu depoimento extraviou-se e, passado algum tempo, apareceu misteriosamente morta. A verdade é que tudo se tinha conjugado para a sua perdição.

Deodato pretende empreender uma campanha a favor do Cavacas mas todos, o Conselheiro Soares, o Milheiro, os seus amigos de $A$ Sementeira, o aconselham a deixar cair o assunto, apenas a consciência o atormentava, impelindo-o a fazer qualquer coisa em favor do Cavacas. Não temos dúvidas que a história seria para ser retomada na continuação do romance, mas, o que é facto, é que nunca chegou até nós.

Para terminar apenas uma palavrinha ou duas acerca do Conselheiro Soares. Desde logo, ele simboliza uma espécie de superego da República, o local de onde irradiam as regras, as normas, o verdadeiro dever ser republicano, ou seja, o que deveria ser a efectiva moral republicana.

Os encontros de Deodato com o familiar do presidente são raros mas marcam decisivamente o narrador. Inicialmente, a personagem é-nos apresentada como criatura "que nunca frequentou a corte e [do mesmo modo] nunca ia a Belém visitar o irmão, agora presidente, numa isenção que excedia de longe a craveira de hábitos e conceitos dominantes" (MIGUÉIS, 1991, p. 125). Esta primeira caracterização fornece-nos, imediatamente, a idiossincrasia do Conselheiro, tão distante do colega Acácio queiroziano.

No entanto, mais significativa são as asserçóes seguinte, com a qual encerraremos este jornada, que emerge no seguimento duma solicitação de um cargo de subdelegado pelo protagonista. O sexagenário magistrado começa por informar que atráves dos laços fraternais seria inútil, pois o Presidente da República era apenas uma figura decorativa (homem da cana verde, na feliz expressão de Teixeira Gomes), nenhum pedido dele seria atendido pelas instituições da república que ajudou a erguer. Reflectindo, em seguida, acerca de solução para o problema afiança "um banqueiro, um purpurado, um antigo conselheiro d'el rei com peso eleitoral ou muitas acções de empresas importantes, um cacique influente, esses sim. Nesta República, por antonomásia democrática, ainda são eles quem manda e pode" (MIGUÉIS, 1991, p. 129). Demonstrando que o exercício do poder judicial não impõe restrições de doutrinas filosóficas ou religiosas, o que se revelaria de difícil realização, mas impede a promiscuidade com a política. No entanto, revela que "chega às vezes a crer que o regime se está entregando em mãos de adversários. Não é preciso ser político, nem mesmo aprovar a orientação geral do regime, para sentir que estamos a abrir as portas à reacção" (MIGUÉIS, 1991, p. 128).

\section{Referências}

ALVES, Ana Maria. Miguéis seareiro. Comunicação ao Simpósio sobre José Rodrigues Miguéis realizado na Universidade de Brown, Massachussets, em novembro de 1981. In: O pão não cai do céu. 4. ed. Lisboa: Editorial Estampa, 1982.

FERREIRA, José Dias. Noções fundamentaes de Philosophia do Direito. Coimbra: Imprensa da Universidade, 1864.

FEYERABAND, Paul. Tratado contra el método. Esquema de una teoría anarquista del conocimiento. Madrid: Editorial Tecnos, 1981.

FINK, Eugen. A filosofia de Nietzsche. Lisboa: Editorial Presença, 1983.

LOURENÇO, Eduardo. As marcas do exílio na obra de J. R. Miguéis. Comunicação ao Simpósio sobre José Rodrigues Miguéis realizado na Universidade de Brown, Massachusets, em novembro de 1981. In: Gente de terceira classe. 5. ed. Lisboa: Editorial Estampa, 1990.

MIGUÉIS, José Rodrigues. Escola do Paraíso. 4. ed. Lisboa: Editorial Estampa, 1981.

Ele era o nosso paizinho. Paços Confusos. Lisboa: Editorial Estampa, 1982a (publicado originalmente em Comércio com o Inimigo, Lisboa: Inova, 1973).

Saudades para D. Genciana. Leah e outras histórias. 7. ed. Lisboa: Editorial Estampa, 1982b.

O pão não cai do céu. 4. ed. Lisboa: Editorial Estampa, 1982c (publicado originalmente no Diário Popular, em 1975 e 1976).

O Milagre segundo Salomé. Vol. I. 3. ed. Lisboa, Editorial Estampa, 1984a.

O Milagre segundo Salomé. Vol. II. 3. ed. Lisboa: Editorial Estampa, 1984b.

Jornais, Revistas \& Canções. O espelho poliédrico. 3. ed. Lisboa: Editorial Estampa, 1989a.

Lembranças em estilhaços. O espelho poliédrico. 3. ed. Lisboa: Editorial Estampa, 1989b.

Janela com paisagem. $O$ espelho poliédrico. 3. ed. Lisboa: Editorial Estampa, 1989c.

Uma Aventura Inquietante. 6. ed. Lisboa: Editorial

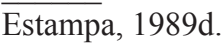

Gente de Terceira classe. 5. ed. Lisboa: Editorial Estampa, 1990.

Idealista no mundo real. 2. ed. Lisboa: Editorial Estampa, 1991.

As ruínas do Coliseu. A amargura dos contrastes. Lisboa: O Independente, 2004 (originalmente publicado na Seara Nova, n. 136, 1928).

MOURA, Maria Lúcia de Brito. A Guerra Religiosa na I República. 2. ed. Lisboa: Centro de Estudos de História Religiosa, Universidade Católica Portuguesa, 2010. 
OLIVEIRA, A. Paulo Dias. O Princípio do Direito, uma polémica oitocentista. Boletim da Faculdade de Direito, Coimbra, Universidade de Coimbra, v. LXXXV, p. 375-445, 2009.

PESSOA, Fernando. O banqueiro anarquista. 6. ed. Lisboa: Antígona, 2006.

QUENTAL, Antero de. Carta a Oliveira Martins de 29 de Junho de 1887. Cartas II. 1881-1891. Org., int. e notas de Ana Maria Almeida Martins. Lisboa/Ponta Delgada: Editorial Comunicação/Universidade dos Açores, 1989.
Recebido: $28 / 05 / 2018$

Aprovado: 02/12/2018

\section{Autor:}

A. PAulo Dias Oliveira

Departamento de Artes e Humanidades da Faculdade de Ciências Humanas e Sociais da Universidade do Algarve. Seminário Livre de História das Ideias (SLHI) - Centro de Humanidades (CHAM) da

Faculdade de Ciências Sociais e Humanas, Universidade Nova de Lisboa/ Universidade dos Açores.

aolivei@ualg.pt 